\title{
TRADE LIBERALISATION AND LABOUR DEMAND WITHIN SOUTH AFRICAN MANUFACTURING FIRMS
}

\author{
L Edwards* and A Behar
}

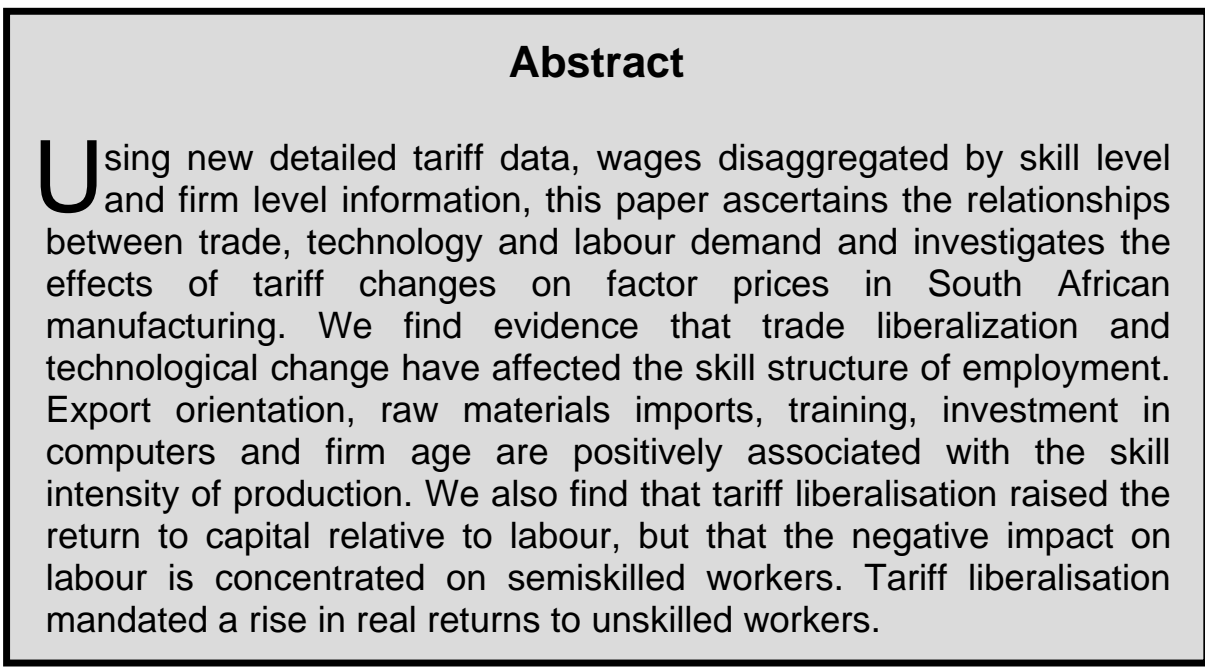

\section{Introduction}

The 1990s heralded a period of increased globalization of the South African economy. In 1992 trade sanctions imposed on South Africa were removed. In 1994 the government committed itself to an ambitious program of tariff liberalisation, as agreed in the Uruguay round of the GATT/WTO negotiations. The democratically elected government in 1994 also implemented a macro-economic policy (GEAR) that was expected to transform South Africa into a "competitive, outward orientated economy" (GEAR, 1996).

In response to these changes, output growth increased and trade rose as a share of production and consumption. Employment growth, however, remained poor. Data, provided by the South African Standardised Industrial Database (Quantec, 2004), indicates that over 700000 semi- and unskilled workers lost formal employment in manufacturing, mining and services between 1990 and 1998. ${ }^{1}$ The coincidence of

\footnotetext{
* Respectively Senior Lecturer, School of Economics, University of Cape Town, Private Bag, Rondebosch 7701 and DPhil student at Nuffield College, Oxford University

Email: ledwards@commerce.uct.ac.za

${ }^{1}$ Much controversy surrounds the reliability of South African statistical series (see Standing et al.
(1996) for a critique). Statistics South Africa's Survey of total employment and earnings (STEE) shows
a decline in formal sector (excluding agriculture) employment during the late 1990s. In contrast, the
} 
'jobless' (or rather 'job-shedding') growth, the rising skill and capital-intensity of production and the increased integration of South Africa into the international economy has stimulated much research on the impact of international trade on labour.

The results of this research are inconclusive. Bell and Cattaneo (1997), Nattrass (1998), Bhorat (1999) and Birdi et al. (2001) argue that trade liberalisation negatively affected employment. In contrast, Fedderke et al. (2003) and Edwards (2001) argue that skill-biased technological change accounts for most of the decline in employment of unskilled labour and that the impact of trade on labour is small. Fedderke et al. (2003:35) for example conclude that "demand factors, and trade liberalization related factors in particular, did not prove to carry a negative impact on labor in South African manufacturing". Edwards (2003) uses manufacturing firm level data to identify whether trade liberalisation has induced "unskilled labour saving technical progress" (or "defensive innovation" as Wood (1994) refers to it). He finds some evidence for it, but the impact is too small for trade liberalisation to account for the decline in employment experienced by these firms.

This study extends existing research on the impact of trade and technology on labour in South Africa in a number of ways. Firstly, we use firm level data to identify factors accounting for differences in the skill structure of employment within manufacturing firms. The specifications of the functions are similar to those of Edwards (2003), but our estimates include factor payments, which are derived from household survey data. Secondly, we use the firm level surveys to estimate changes in economy-wide factor returns arising from trade liberalisation between 1994 and 2003. The empirical methodology, namely the "mandated factor return" regression approach, is similar to that of Fedderke et al. (2003). However, unlike their study where they analyse the impact of product price changes on factor returns, we use tariff data in our estimates and are thus able to directly link trade liberalisation to changes in factor demand. The paper also disaggregates the impact of tariff liberalisation on labour by skill.

We find some evidence that trade liberalization and technological change have affected the skill structure of employment. Export oriented firms, firms importing large shares of their raw materials and firms facing low tariff levels tend to be relatively skill intensive. Indicators of technological change such as training, investment in computers and firm age are also positively associated with the skill intensity of production. In our mandated wage equations, we find that tariff liberalization has raised the return to capital relative to labour. However, the negative impact on labour is concentrated on semiskilled workers and unskilled workers are mandated a real increase in factor returns.

The structure of the paper is as follows. Section 2 presents a brief overview of the theoretical relationship between trade, technology and factors. Section 3 describes the empirical strategy, including the specifications used in the econometric

October Household Surveys show a small rise in employment once agriculture and the informal sector are included. However, in all cases employment growth has been poor. 
analysis. Section 4 presents the data used in the analysis and Section 5 discusses the results of the econometric analysis. Section 6 concludes the paper.

\section{Theory}

There are various avenues through which trade liberalisation affects labour demand. The standard model used for the analysis of trade and labour is the two-sector twofactor two-country Heckscher-Ohlin-Samuelson (HOS) model. ${ }^{2}$ From this model theoretically consistent relationships are drawn between product price movements and factor returns (Stolper-Samuelson theorem) and between technological change and factor returns (Findlay and Grubert, 1959). According to the StolperSamuelson theorem, a decline in the output price of the unskilled labour intensive sector relative to the skill intensive sector lowers the relative wage of unskilled labour relative to skilled labour. This arises because the price shock induces a shift in resources out of the unskilled labour intensive sectors towards the skill intensive sectors, which in turn reduces the relative demand for unskilled labour. Thus, the model predicts that trade liberalisation raises wage inequality in developed economies as the relative price of skill-intensive products rises, but reduces wage inequality in developing economies as the relative price of unskilled labour intensive products rises.

The HOS model, however, faces a number of shortcomings. Firstly, the model predicts ambiguous impacts of trade liberalisation on middle income countries such as South Africa, which compete against both developed and developing economies. The impact on relative factor payments therefore depends on the relative reduction in tariffs or prices in response to the opening of the economy. Davis (1996), for example, develops a framework that shows how liberalisation may raise wage inequality in middle-income economies, despite being globally abundant in unskilled labour. Identifying the impact of tariff liberalisation on middle-income economies is therefore an empirical matter.

The Stolper-Samuelson theorem also describes a long run relationship between relative product price changes and relative factor returns. The short run dynamics as the economy shifts towards its long run equilibrium may have different welfare implications for factors. In the short run, factors are immobile or are sector specific. A reduction in price for a particular sector will therefore negatively affect the returns of all specific factors within that sector (see Neary, 1978). The long-run economy-wide effects may therefore differ from the short run sector or firm specific effects. Analysis using firm level data may therefore present useful insights into the adjustment process within firms as they respond to trade liberalisation.

Trade can also affect factors through its impact upon technological change. Wood (1994, 1995) criticises the standard HOS model in that it assumes technological change is exogenous. In response to greater import competition, firms may raise productivity through "unskilled labour saving technical progress", which he terms "defensive innovation". Pissarides (1997:20) also argues that trade-induced

\footnotetext{
${ }^{2}$ See Slaughter (1998) for a review of many of the international studies.
} 
technological transfers "cause more wage inequality in developing countries because the transfer technology is biased in favor of skilled labour". Wood (1994) argues that the failure to account for "defensive innovation" explains why many international studies find a small impact of trade on employment and factor returns.

In this study we attempt to combine both the firm specific features that determine labour demand as well as capture the general equilibrium impacts of tariff liberalisation on factor demand, as is outlined in the Stolper-Samuelson theorem. The following section discusses the various methodologies utilised.

\section{Empirical methodology}

To estimate the impact of trade liberalisation on labour demand and factor returns in South Africa, we draw on two methodologies. Firstly, we use the National Enterprise (NE) survey to estimate labour demand functions for manufacturing firms in South Africa. The objective is to identify how technology and trade affect the employment decision within firms. We therefore follow Hanson and Harrison $(1995,1999)$ and Edwards (2003) and estimate the function:

$$
\ln \left(\frac{\mathrm{S}}{\mathrm{U}}\right)_{\mathrm{i}}=\alpha+\theta_{1}^{\prime} \Phi_{\mathrm{i}}+\theta_{2}^{\prime} \Omega_{\mathrm{i}}-\sigma \ln \left(\frac{\mathrm{w}_{\mathrm{s}}}{\mathrm{w}_{\mathrm{u}}}\right)_{\mathrm{i}}+\gamma \ln \mathrm{y}_{\mathrm{i}}+\varepsilon_{\mathrm{i}}
$$

where the skilled:unskilled labour ratio is defined as a function of various technology or technical efficiency related variables $(\Phi)$, trade related variables including measures of export and import orientation and tariffs $(\Omega)$, relative wages $\left(\mathrm{w}_{\mathrm{s}} / \mathrm{w}_{\mathrm{u}}\right)$ and value added (y). Equation (1) is consistent with the non-homothetic class of constant elasticity of substitution (CES) production functions. It differs slightly from the specification in Edwards (2003) by allowing for the possibility that the production technology is not homothetic, so that the level of output and technical progress can affect factor proportions (see Sato, 1977). Despite this, CES functions make the restrictive assumption that the elasticity of substitution between all factor pairs is the same and necessarily positive $(\sigma>0) .^{3}$

A positive sign for $\gamma$ means bigger firms are more skill intensive. Positive coefficients on $\Omega$ are consistent with trade-related skill-biased technological change. However, we can't infer any causal effects - trade-induced technological change - from the results as these estimates are in levels. Ideally, we would follow Berman et al. (1994) and Feenstra and Hanson (1999) and estimate equations for changes in factor shares as a function of wages, trade and technology variables. Nonetheless, we are able to gain insights into the relationships between trade related variables and the factor intensity of the production structure.

\footnotetext{
${ }^{3}$ This motivates the use of factor share equations based on a translog cost function. Behar (2004) estimates shares using NE data and finds some occupations could be complements. However, factor share equations estimated in levels produce results entirely consistent with the CES estimates, which present the results of key interest in a more appealing form. Furthermore, presenting the CES estimates allows ready comparison with Edwards (2003).
} 
Equation (1) is estimated separately for the ratios of managerial/professional, skilled/artisanal and semiskilled labour to unskilled labour. It is also estimated for the ratio of more-skilled labour (managers/professionals + skilled/artisanal workers) to less-skilled labour (semiskilled and unskilled workers). The estimation therefore extends initial work by Edwards (2003) by estimating a greater range of relative demand functions. More importantly, this study also constructs wage data from household surveys to be used in the analysis. Together with the output term, this mitigates the potential for omitted variable bias encountered in Edwards (2003).

The second approach to estimating the impact of trade liberalisation on factor demand deals with the general equilibrium impact of tariff changes on factor payments. The NE survey provides a single cross section of data. This lack of consistent employment data over time for each firm precludes an analysis of the dynamic adjustments in factor demand and hence factor prices in response to trade liberalisation. ${ }^{4}$ However, we are able to use the information provided in the survey to identify how trade liberalisation will have affected relative factor demand within a general equilibrium context.

The approach we follow is a direct application of the Stolper-Samuelson relationship: changes in relative product prices alter the relative profitability across sectors and the subsequent shifts of resources affect relative factor demands and hence factor returns. The key equation is the zero profit condition whereby factor prices adjust to ensure zero profits across all industries. Given $\mathrm{J}$ sectors and I factors, the system of zero profit conditions for sectors 1 to $J$ can be expressed as:

$\mathrm{p}_{\mathrm{j}}=\sum_{\mathrm{i} \in \mathrm{I}} \mathrm{a}_{\mathrm{ij}} \mathrm{w}_{\mathrm{i}} \quad \mathrm{j}=1 \cdots \mathrm{J}$

$\mathrm{p}_{\mathrm{j}}$ is the gross output price of product $\mathrm{j} ; \mathrm{w}_{\mathrm{i}}$ is the unit cost of the ith factor input and $a_{i j}$ is the quantity of factor $i\left(v_{i j}\right)$ per unit of output $j\left(q_{i j}\right)$, i.e. $v_{i j} / q_{j}$. The above system of equations assumes perfect factor mobility such that factor costs are harmonised across sectors, hence wages $\mathrm{w}_{\mathrm{i}}$ are not indexed by sector $\mathrm{j}$.

Following Leamer (1996), total differentiating (2) gives:

$$
\mathrm{dp}_{\mathrm{j}}=\sum_{\mathrm{i} \in \mathrm{I}} \mathrm{a}_{\mathrm{ij}} \mathrm{dw}_{\mathrm{i}}+\sum_{\mathrm{i} \in \mathrm{I}} \mathrm{da}_{\mathrm{ij}} \mathrm{w}_{\mathrm{i}} \quad \mathrm{j}=1 \cdots \mathrm{J}
$$

Dividing and multiplying (3) by like terms, dividing by $\mathrm{p}_{\mathrm{j}}$, which under the assumption of perfect competition is equal to cost $\left(\mathrm{c}_{\mathrm{j}}\right)$, and totally differentiating the input intensities $-\mathrm{da}_{\mathrm{ij}}=\mathrm{d}\left(\mathrm{v}_{\mathrm{ij}} / \mathrm{q}_{\mathrm{ij}}\right)-$ we obtain:

\footnotetext{
${ }^{4}$ Edwards (2003) estimates change in labour demand functions for each skill category. However, the employment changes are in a categorical format (increase, decrease, no change) and only cover the period early 1988 to late 1999 . The employment changes thus do not represent the impact of the more extensive tariff liberalisation that has taken place from 1994.
} 


$$
\frac{d p_{j}}{p_{j}}=\sum_{i \in I} \frac{w_{i} a_{i j}}{c_{j}} \frac{d w_{i}}{w_{i}}+\sum_{i \in I}\left(\frac{d v_{i j}}{q_{j}}-\frac{v_{i j} d_{j}}{q_{j}^{2}}\right) \frac{w_{i}}{c_{j}} \quad j=1 \cdots J .
$$

Denoting the percentage change of prices, factor inputs, wages and output by $\hat{p}_{\mathrm{j}}$, $\hat{\mathrm{v}}_{\mathrm{ij}}, \hat{\mathrm{w}}_{\mathrm{i}}$ and $\hat{\mathrm{q}}_{\mathrm{j}}$ respectively, and letting $\theta_{\mathrm{ij}}$ denote the cost share of factor $\mathrm{i}$ in industry $\mathrm{j}\left(\theta_{\mathrm{ij}}=\mathrm{w}_{\mathrm{i}} \mathrm{a}_{\mathrm{ij}} / \mathrm{c}_{\mathrm{j}}\right)$, equation (4) can be simplified to ${ }^{5}$

$$
\hat{\mathrm{p}}_{\mathrm{j}}=\sum_{\mathrm{i} \in \mathrm{I}} \theta_{\mathrm{ij}} \hat{\mathrm{w}}_{\mathrm{i}}-\left(\hat{\mathrm{q}}_{\mathrm{j}}-\sum_{\mathrm{i} \in \mathrm{I}} \theta_{\mathrm{ij}} \hat{\mathrm{v}}_{\mathrm{ij}}\right) \quad \mathrm{j}=1 \cdots \mathrm{J}
$$

The second term on the right hand side of (5) is the difference between the growth in output and the cost share weighted growth in factor inputs and is the standard measure of Total Factor Productivity growth $\left(\mathrm{TFP}_{\mathrm{j}}\right)$. Moving TF̂P to the left hand side, we obtain the primary relationship as derived by Leamer (1996): ${ }^{6}$

$$
\hat{\mathrm{p}}_{\mathrm{j}}+\mathrm{T}_{\hat{\mathrm{FP}}} \mathrm{j}_{\mathrm{j}}=\sum_{\mathrm{i} \in \mathrm{I}} \theta_{\mathrm{ij}} \hat{\mathrm{w}}_{\mathrm{i}} \quad \mathrm{j}=1 \cdots \mathrm{J}
$$

Equation (6) represents a system of equations in which economy-wide factor prices adjust to changes in product prices and technology to restore zero profits in each sector. A key feature of this relationship is that relative factor returns are influenced by both the sector bias of product prices changes and the sector bias of technological change, as outlined in the Stolper Samuelson theorem and Findlay and Grubert's (1959) analysis of Hicks-neutral technological change. Factor biased technological change has no effect, unless second order effects are allowed (see Leamer, 1996).

Given price changes, TFP growth and factor shares, we are in principle able to estimate "mandated" changes in factor prices $\hat{w}$ "that are needed to keep the zero profits condition operative in the face of changes in technology and product prices" (Leamer, 1996:23). These can then be compared with actual wage changes to identify the contribution of product price changes and technological change towards the overall change in factor prices.

However, a number of problems arise in the estimation of the mandated wages using (6). Most importantly, as Feenstra and Hanson (1999: 908) show, if productivity is measured using the dual Tornqvist index of TFP, the mandated wage regression (6) holds as "an identity and cannot offer any predictions of the implied

\footnotetext{
${ }^{5}$ Note that the sum of factor cost shares equals 1 , thus $\sum_{\mathrm{i}} \theta_{\mathrm{ij}}=1$.

${ }^{6}$ This relationship is easily extended to allow for intermediate inputs. In this case, the percentage change in value-added prices replaces the gross output price.
} 
changes in factor prices, other than that which actually occurred." $"$ Thus in its current form it is unable to provide insight into how trade or any other exogenous factor has affected relative factor payments. To transform the identity into an analytical device, it is therefore necessary to identify exogenously induced changes in product prices and productivity, and use these as the dependent variable in (6).

Leamer (1996) identifies the effects of 'globalisation' that work through prices and technological change by assuming that all sectors have the same rate of technological pass through to value-added prices, namely $\hat{\mathrm{P}}_{\mathrm{j}}=-\lambda \mathrm{TF} \mathrm{P}_{\mathrm{j}}$ where $\lambda$ is the pass-through rate. This enables the identification of exogenous price changes $\left(\hat{\mathrm{P}}_{\mathrm{j}}+\lambda \mathrm{TF} \mathrm{P}_{\mathrm{j}}\right)$ and technological change $((1-\lambda) \mathrm{T} \hat{\mathrm{FP}} \mathrm{j})$ from observed data. However, this approach does not address the fact that the relationship essentially remains an identity. Further, we are unable to identify how specific changes such as tariff liberalisation and investment in technology affect relative factor payments.

Feenstra and Hanson (1999) therefore propose and use a two-step approach to identify exogenously induced changes in prices and technology. The first step involves estimating the impact of various structural variables, such as foreign outsourcing, changes in protection and investment in technology, on prices and TFP. In the second stage, the contribution of each structural variable to price changes and/or TFP growth is regressed on cost shares. This approach has also been applied to the United Kingdom by Haskel and Slaughter (2001) and South Africa by Fedderke et al. (2003).

Our objective, given the firm data available, is more modest than these studies. While they attempt to estimate the effect of trade on factor payments via both the price and technology routes, we are primarily interested in assessing the direct impact of tariff liberalisation on factor payments through the price linkage. We firstly impose the small country assumption that prices are fixed exogenously. This assumption also implies that technological change does not feed into lower domestic prices; an assumption that is empirically supported by Fedderke et al. (2003). We also make the simplifying assumption that domestic firms price up to the import parity price. The tariff-induced change in output price can then be calculated as $\hat{p}_{j}=\frac{\left(t_{j, \text { fin }}-t_{j, \text { ini }}\right)}{1+t_{j, \text { ini }}}$ where $t_{j, \text { fin }}$ and $t_{j, \text { ini }}$ represent the final and initial tariff rates for product $\mathrm{j}$. Exploiting the variation across the $\mathrm{J}$ firms in our sample, the mandated wage regression takes the form:

$$
\frac{\left(t_{j, \text { fin }}-t_{j, \text { ini }}\right)}{1+t_{j, \text { ini }}}=\sum_{i \in I} \theta_{i j} \hat{w}_{i}+\varepsilon_{j} \quad j=1 \cdots J
$$

\footnotetext{
${ }^{7}$ The dual Tornqvist index of TFP is defined as the difference in the log change in industry prices and the cost-shared weighted change in factor prices. Substituting this measure of TFP into (6) yields an indentity.
} 
We therefore use firm level factor cost shares $\left(\theta_{\mathrm{ij}}\right)$ and tariff induced changes in product prices facing these firms to estimate $\hat{\mathrm{w}}_{\mathrm{i}}$. Tariff induced changes are calculated using detailed product level tariff data (see later) that are mapped to each firm using product descriptions available in the firm survey. The factor cost shares $\theta_{i j}$ are derived from the firm level survey. Although these are only available for a single time point, the period over which the survey was conducted, 1998-1999, falls roughly mid-way in the period of the measured tariff change, 1994-2003. Our approach is therefore consistent with Feenstra and Hanson (1999) who use the average cost shares of various periods they analyse.

There are, however, some important limitations. Firstly, the assumption of complete pass-through of tariffs to domestic prices is likely to exaggerate the estimated mandated factor payments arising from liberalisation. The impact on relative factor payments, however, is not affected, unless significant differences in pass-through rates are observed across sectors.

Secondly, while this approach captures the direct impact of tariff liberalisation on factor returns, it does not capture the possible indirect effects of trade liberalisation on productivity growth. There is strong evidence that openness, and lower tariffs in particular, have improved total factor productivity in South African manufacturing industries during the 1990s (Jonsson and Subramanian, 2001; Harding and Rattsø, 2005). Improved productivity growth is expected to offset some of the decline in factor remunerations arising from lower product prices.

Finally, as in almost all studies using the mandated wage approach, we assume a one cone HO model in which the product mix does not change substantially. This may be particularly problematic for this study as some industries exposed to rapid liberalisation during the early part of the 1990s may no longer be in existence. The extent, but not the direction, of relative wage shifts is likely to be affected.

\section{Data $^{8}$}

\subsection{Firm survey and factor prices}

The core dataset is from the National Enterprise Manufacturing Survey (NE survey). The NE survey is national in coverage and consists of 941 manufacturing firms, $39 \%$ of which are large firms consisting of more than 50 employees. The survey was administered in late 1999 and early 2000 and covers the period from early 1998. For a thorough description of the data sets see Bhorat and Lundall (2002). An important limitation of the data, however, is that while factor quantities are available, factor prices are not. To supplement the data, we therefore draw information from other sources, as described below. Further details can be obtained from Behar (2004).

The value of capital stock of each firm is provided in the survey. The capital stock data are first adjusted to account for unused capacity using measures of shift

\footnotetext{
${ }^{8}$ The data are available from the authors on request.
} 
capacity utilization. To estimate the return to the capacity-adjusted capital stock, we draw on Fedderke et. al. (2001) and compute the cost of capital as $c=(r-\pi)+\delta+\tau$, where $\Pi$ is the inflation rate; $\delta$ are industry-level depreciation rates that range from $11 \%$ to $16 \%$; and $r$ is the average prime lending rate adjusted for risk. ${ }^{9}$ Risk adjustments to the interest rate variable (r) range from $2 \%$ for large firms older than 5 years to $+5 \%$ for new small firms. Fedderke et al. (2001) use the nominal corporate tax rate for $\tau$, which was $35 \%$ for the fiscal year starting early in 1998 (RSA, 1998). Negash (1999) calculates effective tax rates to be about $15 \%$ below nominal rates for the 1990 s, so we apply a $20 \%$ average effective rate to all firms.

The four occupation groups studied are managerial/professional, skilled/artisan (technicians, welders), semiskilled (machinery operators) and unskilled (labourers, security guards). While there is information on quantities employed, the NE survey does not have wage data. However, as motivated in Behar (2004), average wages based on industry and occupation can be a good approximation to those faced by firms in South Africa. Teal (2000) predicts wages from earnings functions using a matching panel, achieving refined wage measures. Similarly, this paper uses features common to the NE dataset and the 1997 October Household Survey (OHS). For each occupation, the characteristics available in both data sources are:

- economic activity (broken down into nine industries);

- province group (the nine provinces were ex post broken down into two groups with similar wages);

- individual trade union membership dummy (household data); collective bargaining and bargaining council membership dummy (firm data).

Wage construction entails calculating the survey-adjusted means for selected categories of people from the household survey and attaching these wages to firms with the same characteristics. We do this for each occupation. The 9 industries, 2 province groups and information on union membership imply 36 different possible combinations of characteristics that can be used to determine occupational wages. Estimating wages at this level of disaggregation, however, is not optimal as some categories would have few observations and hence imprecisely estimated wages. As motivated and detailed in Behar (2004), we selectively combine some of the categories for each occupation. As a result, there are seven wage categories for managerial/professional labour, fifteen for skilled/artisanal workers, ten for semiskilled labour and fourteen for the unskilled.

Finally, there is substantial international evidence that firm size is an important determinant of firm-specific wages (Oi and Idson, 1999). Behar (2004) also analyses the potentially severe consequences of ignoring such effects in wage construction. We therefore inflate/deflate the calculated wages for firm size effects using estimates from Bhorat and Lundall (2002).

\footnotetext{
${ }^{9}$ We thank Johannes Fedderke for providing the depreciation rate data.
} 
The estimated factor price variables are used in the relative labour demand function (1) and are also used to calculate the factor shares and total factor costs in the mandated wage regressions (7). Labour costs are obtained by multiplying labour quantities by the constructed wage. Capital costs are calculated by multiplying the capacity-adjusted capital stock by the calculated cost of capital. Total factor cost is the sum of factor costs. Table 1 contains further descriptions of the variables used in the regression analysis.

\subsection{Tariff liberalisation}

The impact of trade liberalisation on labour will depend on the extent to which the economy has liberalised its trade. This issue is particularly relevant in South Africa as there is substantial disagreement on the extent to which protection has fallen since the 1980s (Holden, 1992; Bell, 1997; Belli et al., 1993; Fedderke and Vaze, 2001). ${ }^{10}$

Table 2 presents sector level information on protection and the change in protection between 1994 and 2003. These estimates are derived from the South African tariff schedules, which are specified at the 8-digit Harmonised System level. These rates include ad valorem equivalents of formula, specific and mixed duties, which are set equal to the collection rates if the latter exceeded the ad valorem component of the scheduled rates. Lack of consistent import price data and quantity units prohibited the calculation of ad valorem equivalents according to the standard approach (tariff value / f.o.b import value). The use of collection rates leads to an under-estimate of protection levels as highly protected products may not be imported and exemptions on duty are frequently granted (e.g. imported intermediate inputs are often duty free when the final product is to be exported). We also adjust these rates for surcharges using data obtained from Quantech (2004).

According to the data, average tariffs in manufacturing declined from $14.5 \%$ to 9.3\% between 1994 and 2003. If surcharges are included, average protection in manufacturing in 1994 was $19.5 \%$. The decline in protection during the 1990s is therefore more severe once surcharges are included. Looking at the sector level tariff rates for 1994, very high protection rates (more than 30\%, inclusive of surcharges) are found in tobacco, textiles, wearing apparel, footwear and furniture. Low rates (less than 10\%) are found in coke and refined petroleum, basic chemicals and basic metals.

Table 2 also presents the average annual change in tariffs between 1988 and 2002 for each sector. Large declines in scheduled tariff rates inclusive of surcharges (more than 13\% per annum) are found in textiles, wearing apparel, footwear, communication equipment and other manufacturing. Despite the large declines, tariffs in many of these sectors (wearing apparel, textiles and footwear) remain high. Sectors experiencing small declines in protection (less than 5\% per annum) include tobacco, wood products, paper products, coke and petroleum and basic iron and steel.

\footnotetext{
${ }^{10}$ For a detailed discussion on trade liberalisation see Holden (1992), Bell (1997) and Jenkins et al. (1997).
} 
Table 1: Variable names and descriptions

\begin{tabular}{|c|c|}
\hline Variable name & Description \\
\hline \multicolumn{2}{|l|}{ Factor Demand } \\
\hline \multicolumn{2}{|l|}{ Labour Quantities } \\
\hline Skilled Labour & $\begin{array}{l}\log \left[\text { full time }+0.5^{*}(\text { part time })\right] \text { of managerial/professional, } \\
\text { skilled/artisanal or semiskilled labour }\end{array}$ \\
\hline Unskilled Labour & $\log \left[\right.$ full time $+0.5^{*}$ (part time $\left.)\right]$ of unskilled labour \\
\hline More skilled & $\begin{array}{l}\log \left[\text { full time }+0.5^{*}(\text { part time })\right] \text { of managerial/professional, and } \\
\text { skilled/artisanal labour }\end{array}$ \\
\hline Less skilled & $\begin{array}{l}\log \left[\text { full time }+0.5^{*}(\text { part time })\right] \text { of semiskilled and unskilled } \\
\text { labour }\end{array}$ \\
\hline \multicolumn{2}{|l|}{ Trade related variables } \\
\hline Exporter & Dummy variable for firms that export \\
\hline Tariff 2000 (1994) & Tariff rates for 2000 (1994) \\
\hline Tariff: market share & $\begin{array}{l}\text { Dummy for firms expecting recent tariff changes to reduce their } \\
\text { South African market share }\end{array}$ \\
\hline Tariff: export competitiveness & $\begin{array}{l}\text { Dummy for firms expecting recent tariff changes to enhance } \\
\text { their export competitiveness }\end{array}$ \\
\hline \multicolumn{2}{|l|}{ Technology related variables } \\
\hline$\% \mathrm{M}$ in raw materials & Proportion of raw materials that are imported \\
\hline Training share of I & $\begin{array}{l}\text { Share of total investment spent on training the workforce during } \\
\text { last financial year }\end{array}$ \\
\hline Computer share of I & $\begin{array}{l}\text { Share of total investment spent on computers during last } \\
\text { financial year }\end{array}$ \\
\hline Machinery share of I & $\begin{array}{l}\text { Share of total investment spent on machinery and equipment } \\
\text { during last financial year }\end{array}$ \\
\hline Log Age & Log of age of firm in 1999 \\
\hline Wage ratio & $\begin{array}{l}\text { Log of ratio of skilled to unskilled or more-skilled to less- } \\
\text { skilled annual } 1998 \text { wages }\end{array}$ \\
\hline Value Added & $\begin{array}{l}\log \left[T^{*}(1-r m)\right] \text {, where } T \text { is turnover in } \mathrm{R} \text { millions and } \mathrm{rm} \text { is the } \\
\text { percentage of total costs consisting of raw materials costs (See } \\
\text { Behar }(2004))\end{array}$ \\
\hline \multicolumn{2}{|l|}{ Mandated Wages } \\
\hline Factor shares & $\begin{array}{l}\frac{\mathrm{w}_{\mathrm{i}} \mathrm{x}_{\mathrm{i}}}{\sum_{\mathrm{j}} \mathrm{w}_{\mathrm{j}} \mathrm{x}_{\mathrm{j}}} \text {, where } w \text { is the wage or cost of capital, } \mathrm{x} \text { is the } \\
\text { labour quantity or capacity-adjusted value of fixed capital stock, } \\
\text { and the denominator is total factor cost }\end{array}$ \\
\hline$\hat{p}_{j}$ & $\begin{array}{l}\text { Change in tariff from } 1994 \text { to } 2003 \text {, calculated as } \text { (tariff }_{2003^{-}} \\
\text {tariff } \\
1994) /\left(1+\text { tariff }_{1994)} \text {. Tariff rates at the } 4 \text {-digit Standard }\right. \\
\text { Industrial Classification level are allocated to firms on the basis } \\
\text { of their major product produced. }\end{array}$ \\
\hline Cost of capital & $\begin{array}{l}(r-\pi)+\delta+t+\varphi \text {, where } r \text { is the prime lending rate, } \pi \text { is } \\
\text { inflation, } \delta \text { is the depreciation, } t \text { is the average effective } \\
\text { corporate tax rate and } \varphi \text { is a risk adjustment for small and/or } \\
\text { new firms. }\end{array}$ \\
\hline
\end{tabular}


Table 2: Measures of protection and change in protection for manufacturing

\begin{tabular}{|c|c|c|c|c|c|c|}
\hline & \multicolumn{2}{|c|}{ Tariffs excl surcharges } & \multirow{2}{*}{$\begin{array}{l}\text { Tariffs incl } \\
\text { surcharges } \\
1994\end{array}$} & \multicolumn{2}{|c|}{ Change excl surcharges } & \multirow{2}{*}{\begin{tabular}{l}
\multicolumn{1}{c}{$\begin{array}{c}\text { Change } \\
\text { incl } \\
\text { surcharges }\end{array}$} \\
$1994-03$
\end{tabular}} \\
\hline & 1994 & 2003 & & 2003 & 1994-03 & \\
\hline Food & 11,9 & 11,8 & 18,8 & 11,8 & $-0,1$ & $-5,9$ \\
\hline Beverages & 6,5 & 14,3 & 29,3 & 14,3 & 7,3 & $-11,6$ \\
\hline Tobacco & 29,2 & 36,0 & 41,7 & 36,0 & 5,3 & $-4,0$ \\
\hline Textiles & 38,1 & 22,6 & 41,3 & 22,6 & $-11,3$ & $-13,2$ \\
\hline Wearing apparel & 62,5 & 35,0 & 75,1 & 35,0 & $-16,9$ & $-22,9$ \\
\hline Leather products & 16,7 & 11,6 & 25,9 & 11,6 & $-4,4$ & $-11,4$ \\
\hline Footwear & 36,8 & 22,7 & 48,0 & 22,7 & $-10,3$ & $-17,1$ \\
\hline Wood products & 11,0 & 9,1 & 14,5 & 9,1 & $-1,7$ & $-4,7$ \\
\hline Paper products & 9,8 & 6,2 & 11,3 & 6,2 & $-3,2$ & $-4,6$ \\
\hline Printing and publishing & 9,5 & 4,8 & 16,1 & 4,8 & $-4,3$ & $-9,8$ \\
\hline Coke and petroleum & 5,1 & 3,3 & 5,1 & 3,3 & $-1,7$ & $-1,8$ \\
\hline Basic chemicals & 8,0 & 1,7 & 8,1 & 1,7 & $-5,9$ & $-5,9$ \\
\hline Other chemicals & 11,6 & 4,5 & 16,2 & 4,5 & $-6,4$ & $-10,1$ \\
\hline Rubber products & 16,5 & 11,4 & 18,6 & 11,4 & $-4,4$ & $-6,0$ \\
\hline Plastic products & 17,5 & 9,8 & 19,8 & 9,8 & $-6,6$ & $-8,4$ \\
\hline Glass products & 10,1 & 7,7 & 17,2 & 7,7 & $-2,2$ & $-8,1$ \\
\hline Non-metallic minerals & 11,3 & 5,6 & 15,0 & 5,6 & $-5,1$ & $-8,2$ \\
\hline Basic iron and steel & 8,2 & 4,3 & 8,8 & 4,3 & $-3,6$ & $-4,1$ \\
\hline Non-ferrous metals & 10,4 & 2,2 & 10,8 & 2,2 & $-7,4$ & $-7,7$ \\
\hline Metal products & 13,6 & 8,1 & 18,3 & 8,1 & $-4,8$ & $-8,6$ \\
\hline Machinery and equipment & 7,4 & 3,7 & 10,4 & 3,7 & $-3,5$ & $-6,1$ \\
\hline Electrical machinery & 13,5 & 7,7 & 18,3 & 7,7 & $-5,1$ & $-8,9$ \\
\hline equipment & 14,6 & 3,1 & 24,2 & 3,1 & $-10,1$ & $-17,0$ \\
\hline Professional and scientific & 5,7 & 0,3 & 12,2 & 0,3 & $-5,1$ & $-10,6$ \\
\hline Motor vehicles & 24,1 & 15,7 & 25,9 & 15,7 & $-6,8$ & $-8,1$ \\
\hline Other transport & 7,0 & 0,9 & 12,3 & 0,9 & $-5,7$ & $-10,2$ \\
\hline Furniture & 21,5 & 17,7 & 32,1 & 17,7 & $-3,1$ & $-10,9$ \\
\hline Other manufacturing & 15,1 & 6,0 & 26,5 & 6,0 & $-7,9$ & $-16,2$ \\
\hline Weighted average & 14,5 & 9,3 & 19,5 & 9,3 & $-5,6$ & $-8,8$ \\
\hline
\end{tabular}

\section{Results}

We first present the results of the labour demand functions and proceed to the estimates of the mandated wage regressions. 


\subsection{Labour demand}

Table 3 presents the results of estimates of equation (1) for all firms and for the restricted sample of large firms.

Table 3: Relative labour demand equations

\begin{tabular}{|c|c|c|c|c|c|c|c|c|}
\hline & \multicolumn{2}{|c|}{ ManandProf/Unskilled } & \multicolumn{2}{|c|}{ SkilandArt/Unskilled } & \multicolumn{2}{|c|}{ Semi/Unskilled } & \multicolumn{2}{|c|}{$\begin{array}{l}\text { More-skilled / } \\
\text { Less-skilled }\end{array}$} \\
\hline & All & Large & All & Large & All & Large & All & Large \\
\hline & 1 & 2 & 3 & 4 & 5 & 6 & 7 & 8 \\
\hline Exporter & & $0,482^{*}$ & & $0,443^{*}$ & & & & \\
\hline Tariff 2000 & $-1,489 *$ & $-1,068$ & $-2,184 * * *$ & $-1,835^{* *}$ & $-1,267$ & $-1,510^{*}$ & $-2,588 * * *$ & $-3,230 * * *$ \\
\hline$\% \mathrm{M}$ in raw materials & $0,718^{* *}$ & $1,631 * * *$ & $0,858 * * *$ & $1,574 * * *$ & $0,857^{* * *}$ & $1,407 * * *$ & $0,336^{* *}$ & $0,829 * * *$ \\
\hline $\begin{array}{l}\text { Tariff: market share } \\
\text { Tariff: export } \\
\text { competitiveness }\end{array}$ & $-0,506 * * *$ & $-0,401^{*}$ & $-0,524 * * *$ & & $\begin{array}{l}-0,356^{*} \\
-0,439^{* *}\end{array}$ & & & \\
\hline Training share of I & $0,013^{* *}$ & & $0,0140 * *$ & & $0,016^{* * *}$ & $0,020 * * *$ & & \\
\hline Computer share of I & & $1,479 * * *$ & & $1,746^{* * *}$ & & $1,671 * * *$ & $0,382 * *$ & $1,285^{* * *}$ \\
\hline Machinery share of I & & & & & & & $-0,388 * * *$ & \\
\hline Log Age & $-0,200 * *$ & $-0,273^{* *}$ & $-0,188^{*}$ & $-0,294^{* *}$ & $-0,176^{*}$ & & $-0,080^{*}$ & \\
\hline Relative Wage & $-1,058 * * *$ & $-0,998 * * *$ & $-0,874 * * *$ & $-0,843 * * *$ & $-1,243 * * *$ & $-1,741 * * *$ & $-0,270 * * *$ & $-0,089$ \\
\hline Log Value Added & 0,036 & $0,152 * *$ & 0,024 & $0,123^{*}$ & 0,081 & $0,185^{* *}$ & $-0,059 * *$ & $0,079^{*}$ \\
\hline Constant & $0,846^{* *}$ & $-0,404$ & 0,357 & $-0,843^{*}$ & 0,188 & $-1,463^{* * *}$ & $-0,133$ & $-1,566^{* * *}$ \\
\hline Number of obs & 292 & 211 & 292 & 232 & 292 & 201 & 470 & 233 \\
\hline F statistic & $8,8^{* * *}$ & $7,9^{* * *}$ & $8,03 * * *$ & $7,99 * * *$ & $8,73 * * *$ & $13,79 * * *$ & $12,96^{* * *}$ & $14,46^{* * *}$ \\
\hline $\mathrm{R}$-squared & 0,16 & 0,29 & 0,14 & 0,24 & 0,15 & 0,24 & 0,16 & 0,24 \\
\hline
\end{tabular}

Data availability only enables us to estimate the relative labour demand equations in levels and not changes. It is thus difficult to identify the direction of the causal relationship between the explanatory variables and the skill intensity of production suggested by the estimated coefficients. Nevertheless we find relationships between trade, technology and relative factor demand that are consistent with theoretical expectations.

Looking first at the trade related variables, we find that firms that import a larger proportion of their raw materials are consistently more skill intensive. For example, column 7 suggests that, ceteris paribus, a firm that sources ten percentage points more of its raw materials abroad will have a workforce that is 3,36\% more skill intensive. Similar results are found in Edwards (2003), but this relationship is now shown to be robust to the inclusion of small firms. The relationship between skill intensity and imported raw materials is consistent with Pissarides (1997), who argues that imports may complement skilled labour. 
The data also produces constant evidence that firms experiencing higher tariffs are less skill-intensive, especially in skilled and artisanal labour, where a ten percentage point higher tariff rate is associated with $21,84 \%$ lower demand relative to unskilled labour. Less skill intensive firms are also the most concerned about losing market share because of tariffs changes. This is consistent with the view that tariff liberalisation induces "defensive innovation" and thereby raises the skill structure of employment within firms. However, the relationship most likely reflects relatively high tariffs imposed on low skilled and labour intensive sectors such as clothing, footwear and textiles. These tariffs reveal South Africa's comparative advantage, which lies in natural resource intensive products and not labour-intensive goods (Nordas, 1996; Edwards and Golub, 2004) and the effect of rent-seeking, particularly within the clothing and textile sectors (GATT, 1993: 170).

Firms expecting to be more export competitive because of lower tariffs also tend to be less skill-intensive, but this result appears to be driven by the smaller firms as the variable is insignificant for the large firm sample. For large firms, the export dummy is moderately significant and positive, suggesting greater skill-intensity for export orientation. Similar results are found by Edwards (2003) and Rankin et al. (2004) who also find that large firms are more export oriented. The size and skill relationship may reflect the importance of economies of scale and productivity in accessing the export market.

The results also show a positive association between skill-intensity of production and the various indicators of technology. Firms that train more tend to have more skilled workforces, suggesting that training complements rather than substitutes skills. This is also true for investment in computers, where for example a ten percentage point rise in the proportion of computer investment corresponds to a 17,46 percentage rise in the proportion of skilled and artisanal workers in large firms. While the effect is far larger than for training, the importance of computers is consistent across skill types for large firms only. New firms are also more skillintensive, reflecting the use of newer technology that complements skilled labour.

For large firms, the significant positive coefficients on Value Added present consistent evidence that bigger firms are more intensive in skills of various types. However, the contradiction between columns 7 and 8 suggests the relationship between output and skill intensity may be non-linear and that this relationship only materialises beyond some level of output.

Looking at disaggregated occupations in columns 1-6, all the relative wage coefficients are significant. For example, a $1 \%$ rise in the relative managerial and professional/unskilled wage would lead to an approximately equal fall in relative demand for managerial and professional labour. As one would expect, semiskilled labour appears to be a closer substitute for unskilled labour than the higher skilled occupations are. However, but for column 5, the estimates are similar enough for the elasticity restrictions assumed by the CES technology mentioned in section 2 not to be of concern in this application. Columns 7 and 8 suggest that more- and less-skilled labour are not as easily substitutable - the insignificant coefficient for 
large firms suggesting they may not be at all - which is to be expected as the inputs measured are more aggregated. ${ }^{11} 12$

In a 2-factor estimate, the absolute value of the conditional labour demand elasticity for factor $i$ is $\left|\eta_{\mathrm{i}}\right|=\left(1-\mathrm{s}_{\mathrm{i}}\right) \sigma$ (Cahuc and Zylberberg, 2004), where $s_{i}$ is that factor's cost share. Using the sample average factor share, the estimates in Table 3 yield the demand elasticities given in Table 4. Equation 1 is not the ideal platform for finding these elasticities, but the results nonetheless suggest the data adequately control for the effects of wages on labour demand.

Table 4: Labour demand elasticities

\begin{tabular}{llccccc}
\hline & \multicolumn{2}{c}{$\begin{array}{c}\text { Man and Prof / } \\
\text { Unskilled }\end{array}$} & \multicolumn{2}{c}{$\begin{array}{c}\text { Skilled andArtisan / } \\
\text { Unskilled }\end{array}$} & \multicolumn{2}{c}{ Semi / Unskilled } \\
& All & Large & All & Large & All & Large \\
\hline Skilled & 0,62 & 0,58 & 0,57 & 0,57 & 0,52 & 1,04 \\
Unskilled & 0,44 & 0,41 & 0,30 & 0,28 & 0,73 & 0,70 \\
\hline
\end{tabular}

Almost all estimates fall comfortably within the $[0.15,0.75]$ interval found in the majority of international studies (Hamermesh, 1993). Estimates are consistent with those reported by Nattrass (2004), albeit slightly less elastic, and are close to those found by Behar (2004).

Having used Table 3 to provide a picture of some of the relationships between technology, trade, wages and relative skill demand, we now look at some indicators of the expected effects of tariff changes on relative wages.

\subsection{Mandated wage changes}

To identify the economy-wide effect of tariffs on factor payments, we estimate the mandated wage regression (7) using the national level weights provided in the survey. The results are presented in Table 5 .

The estimated coefficients reflect the percentage change in factor returns that are consistent with product price changes induced by tariff liberalisation (including the reduction in surcharges) between 1994 and 2003. As noted earlier, we do not estimate the effect on factor returns from trade-induced changes in TFP. Also presented in Table 5 are the mandated changes in skill premium, calculated as the difference in mandated returns across factors. These estimates enable an analysis that is more consistent the Stolper-Samuelson theorem that predicts changes in relative factor payments.

\footnotetext{
${ }^{11}$ The relative wage is produced by restricting the coefficients on managerial/professional and skilled/artisan wages to be equal and those on semiskilled and unskilled to be equal.

${ }^{12}$ Together with the higher values in columns 5 and 6 , the results also suggest the production technology would be usefully represented by a two-level CES function.
} 
Some caution is required in interpreting the coefficients. The estimated changes in factor returns do not necessarily reflect actual changes experienced as numerous other changes to the factor and product markets between 1994 and 2003 will also have affected factor returns. The coefficients, however, provide some insight into the general equilibrium contribution of trade liberalisation to changes in factor returns.

Table 5: Mandated factor returns from tariff liberalisation, 1994-2003

\begin{tabular}{lll}
\hline & All firms & Large firms \\
\hline Capital and labour according to skill & & \\
Mandated changes in factor returns & & \\
Managerial and Professional & $-0,089^{* * *}$ & $-0,050$ \\
Skilled and Artisanal & $-0,106^{* * *}$ & $-0,141$ \\
Semiskilled & $-0,152^{* * *}$ & $-0,187^{* * *}$ \\
Unskilled & $-0,067^{* * *}$ & $-0,075^{* *}$ \\
Capital & $-0,069^{* * *}$ & $-0,051^{* * *}$ \\
Mandated changes in relative factor returns & & \\
Man and Prof - unskilled & $-0,022$ & 0,026 \\
Skilled and Artisan - unskilled & $-0,039$ & $-0,066$ \\
Semiskilled - unskilled & $-0,085^{* * *}$ & $-0,112^{* * *}$ \\
Man and Prof - capital & $-0,020$ & 0,002 \\
Skilled and Artisan - capital & $-0,037$ & $-0,09$ \\
Semiskilled - capital & $-0,083^{* * *}$ & $-0,136^{* * *}$ \\
Unskilled - capital & 0,002 & $-0,024$ \\
Capital and labour & & \\
Mandated changes in factor returns & & \\
Labour & $-0,108^{* * *}$ & $-0,134^{* * *}$ \\
Capital & $-0,069^{* * *}$ & $-0,048^{* * *}$ \\
Mandated changes in relative factor returns & & \\
Labour - capital & $-0,039^{* * *}$ & $-0,086^{* * *}$ \\
$\%$ change in product price & $-0,089$ & $-0,087$ \\
\hline Notes: $* *$ * & & \\
\hline
\end{tabular}

Notes: $*, * *, * *$ denote significant at $10 \%, 5 \%$ and $1 \%$, respectively. Mandated changes in relative factor returns are calculated as the difference in the estimated mandated wage coefficients.

As shown in Table 5, tariff liberalisation between 1994 and 2003 mandated a decline in returns to all factors. However, tariff liberalisation also reduced product prices by approximately $9 \%$ during this period, implying that real factor returns have not necessarily fallen. Tariff liberalisation has negatively affected demand for semiskilled workers the most, resulting in a mandated decline in wages of $15,2 \%$ in the complete sample and $18,7 \%$ in the large firm sample. Skilled and artisanal workers also experienced a relatively large decline in mandated wages of between $10,6 \%$ and $14,1 \%$. The mandated decline in wages for skilled, artisanal and semiskilled workers exceeds the decline in product prices arising from tariff liberalisation, pointing to a decline in real wages. Unskilled labour appears to be the 
least affected. Tariff liberalisation mandated a decline in unskilled wages of $6,9 \%$ in the full sample and $5.1 \%$ in the large firm sample.

To assess the effect on wage inequality, Table 5 also presents the difference in mandated wage changes between various factors. We find no unambiguous increase or decrease in mandated wage inequality over the period. The mandated return to unskilled labour exceeded all other skill categories, but was only significantly different from semiskilled labour.

Looking at the return to capital relative to aggregated labour, we find that tariff liberalisation has raised the demand for capital relative to labour. Tariff liberalisation mandated a $10,8 \%$ to $13,4 \%$ decline in the return to labour compared to a $4,8 \%$ to $6,9 \%$ decline in the return to capital. When compared to product price changes arising from liberalisation, this implies a real decline in the return to labour and a real rise in the return to capital.

The difference in returns is also significant and suggests that tariff liberalisation mandated a rise in return to capital relative to labour of between 3,9 and 8,6 percentage points. However, the results for disaggregated labour show that the decline in the relative return to labour is largely driven by the decline in the return to semi-skilled labour. These results differ substantially from those of Fedderke et al. (2003) who find that product price movements benefited labour as opposed to capital.

Although tariff liberalisation mandated a decline in the return to aggregate labour, real wage rigidities may have translated these wage effects into employment effects. Lack of wage moderation in the face of increased international competition may have encouraged firms to shed labour, contributing to the job-shedding growth observed in the 1990s.

\section{Conclusion}

This study uses firm level data to investigate the impact of trade liberalization and technological change on the demand for factors in South Africa. Two approaches are followed. Firstly, relative labour demand functions are estimated. Using the variation in employment responses across firms, we are able to identify how the skill intensity of production is related to a range of technology and trade related variables. The second approach uses the mandated wage framework developed by Leamer (1996). In this approach, the production characteristics of the firm are used to estimate changes in factor prices that are consistent with changes in tariffs between 1994 and 2003. The methodology draws upon the general equilibrium relationship outlined in the Stolper-Samuelson theorem.

We find some evidence that trade liberalization and technological change have affected the skill structure of employment. Export oriented firms, firms importing large shares of their raw materials and firms facing low tariff levels tend to be relatively skill intensive. Indicators of technological change such as training, investment in computers and age are also positively associated with the skill 
intensity of production. In our mandated wage equations, we find that tariff liberalization has raised the return to capital relative to labour, but that the negative impact on labour is concentrated on semiskilled workers. Unskilled workers are mandated a real increase in factor returns.

\section{References}

Behar, A (2004): "Estimates of labour demand elasticities and elasticities of substitution using firmlevel manufacturing data", CSSR Working Paper no. 98. Cape Town: Centre for Social Science Research, University of Cape Town.

Bell T, and Cattaneo N (1997): "Foreign trade and employment in South African manufacturing industry", International Labour Organisation Occasional Report no. 4, Geneva: International Labour Organisation Employment and Training Department.

Bell, T (1997): “Trade policy,” in J. Michie and V. Padayachee, V. (eds.), The Political Economy of South Africa's Transition, London: Dryden Press.

Belli P, Finger, M and Ballivian, A (1993): "South Africa: A review of trade policies. World Bank Informal Discussion Papers on Aspects of the South African Economy no. 4", Washington DC: The World Bank Southern Africa Department.

Berman, E, Bound, J and Griliches, Z (1994): "Changes in the demand for skilled labor within U.S. manufacturing: Evidence from the annual survey of manufactures", Quarterly Journal of Economics, 109(2).

Bhorat, H (1999): "Decomposing sectoral employment trends in South Africa", paper presented at the Trade and Industrial Policy Secretariat Annual Forum, Muldersdrift.

Bhorat, H Lundall, L (2002): "Employment, wages and skills development: firm specific effects evidence from two firm surveys in South Africa" Development Policy Research Institute Working Paper 68(2)

Birdi, A, Dunne, A and Watson, D (2001): "Labour demand and trade in South Africa: A dynamic panel analysis", paper presented at the Annual Conference on Econometric Modelling for Africa, July 2001.

Cahuc, P and Zylberberg, A (2004): Labor Economics, London: MIT Press.

Davis, D (1996): “Trade liberalization and income distribution”, NBER Working Paper No. w5693

Edwards, L (2001): "Globalisation and the occupational structure of employment in South Africa", South African Journal of Economics, 69(1).

Edwards, L (2003): "Firm level analysis of trade, technology and employment in South Africa", Journal of International Development, 15.

Edwards L, Golub S (2002): "South Africa's international cost competitiveness and productivity", World Development, 32(8).

Fedderke J, Shin Y, Vaze P. 2003. Trade and labour usage: An examination of the South African manufacturing industry. Econometric Research Southern Africa Working Paper no. 15. University of Witwatersrand: Johannesburg.

Fedderke, J and Vaze, P (2001): "The nature of South Africa's trade patterns by economic sector, and the extent of trade liberalisation during the course of the 1990's", South African Journal of Economics, $69(3)$. 
Fedderke, J, Kayemba, J, Henderson, S, Mariotti, M and Vaze, P (2001): "Changing factor market conditions in South Africa: the capital market - a sectoral description", Development Southern Africa $18(4)$.

Feenstra, R and Hanson, G (1999): "The impact of outsourcing and high-technology capital on labor: Estimates for the United States, 1979-90”, Quarterly Journal of Economics, August.

Findlay, R and Grubert, H (1959): "Factor intensities, technological progress and terms of trade", Oxford Economic Papers, February.

GATT (1993): Trade Policy Review: South Africa, Geneva: World Trade Organisation Secretariat.

GEAR (1996): Growth, employment and redistribution: A macroeconomic strategy, Pretoria: South African government.

Hamermesh, D (1993): Labor Demand, Princeton: Princeton University Press.

Holden, M (1992): "The Structure and Incidence of Protection in South Africa", in Black, P and B Dollery (eds), Leading Issues in South African Microeconomics, Johannesburg: Southern book publishers.

Hanson, G, Harrison A (1995): "Trade, technology and wage inequality", National Bureau of Economic Research Working Paper no. 5110.

Harding, T. and Rattsø, J. (2005): “The barrier model of productivity growth: South Africa”, Trade and Industry Policy Strategies Working Paper 5 - 2005.

Harrison, A, Hanson G (1999): "Who gains from trade reform? Some remaining puzzles", Journal of Development Economics 59(1).

Haskel, J, Slaughter, M (2001): "Trade, technology and U.K. wage inequality", Economic Journal, 111(468).

Jenkins, C, Bleaney, M, Holden, M and Siwisa, N (1997): “A review of South Africa's trade policy", paper presented at the Trade and Industrial Policy Annual Forum, Muldersdrift.

Jonsson, G. and Subramanian, A, (2001): "Dynamic gains from trade: Evidence from SA", IMF Staff Papers, 48, 1: 197-224.

Leamer, E (1996): "In search of the Stolper Samuelson effects on U.S. wages", National Bureau of Economic Research Working Paper no. 5427.

Nattrass, N (1998): "Globalisation, employment and labour market institutions in South Africa”, South African Network for Economic Research Working Paper no. 14.

Nattrass, N (2004): "Unemployment and AIDS, the Social-democratic challenge for South Africa", Development Southern Africa 21(1).

Neary, J (1978): "Short-run capital specificity and the pure theory of international trade", The Economic Journal, 88.

Negash, M (1999): "Corporate tax and capital structure: some evidence and implications", The Investment Analysts Journal 56, no. 2.

Nordas, H (1996): "South African manufacturing industries - Catching up or falling behind?" The Journal of Development Studies, 32(5).

Oi, W., and T. Idson (1999): Firm size and wages; in Ashenfelter, O and D Card (eds.). "Handbook of Labour Economics Volume 3C"; Elsevier North Holland, Amsterdam. 
Pissarides C (1997): "Learning by trading and the returns to human capital in developing countries", The World Bank Economic Review 11(1).

Quantec (2004): South African Standardised Industry Database, Quantec Research. Available from http://www.tips.org.za/data/

Rankin, N, Söderbom, M and Teal, F (2004): "Exporting from manufacturing firms in Sub-Saharan Africa: Micro evidence for macro outcomes", Paper presented at the TIPS/DPRU conference, Somerset West.

Republic of South Africa (1998): Budget Review 1998. Pretoria

Sato, R (1977): "Homothetic and Non-Homothetic CES Production Functions", American Economic Review, 67(4).

Standing, G, Weeks, J and Sender, J (1996): Restructuring the labour market, Geneva: International Labour Organisation.

Slaughter, M (1998): "What are the results of product-price studies and can we learn from their differences?", National Bureau of Economic Research Working Paper no. 6591.

Teal, F (2000): "Real wages and the demand for skilled and unskilled male labour in Ghana's manufacturing sector: 1991-1995", Journal of Development Economics 61.

Wood, A (1994): North South Trade, Employment and Inequality, Oxford: Oxford University Press.

Wood, A (1995): “How trade hurt unskilled workers", Journal of Economic Perspectives, 9(3). 